\title{
31. PETROLOGY OF BASALT DRILLED FROM THE GALAPAGOS SPREADING CENTER, DEEP SEA DRILLING PROJECT LEG 54
}

\author{
R. V. Fodor, Department of Geosciences, North Carolina State University, Raleigh, North Carolina \\ J. L. Berkley, K. Keil, and J. W. Husler, Department of Geology, and Institute of Meteoritics, \\ University of New Mexico, Albuquerque, New Mexico \\ and \\ M.-S. Ma and R. A. Schmitt, Department of Chemistry and the Radiation Center, \\ Oregon State University, Corvallis, Oregon
}

\begin{abstract}
Basalt recovered from Site 424, $22 \mathrm{~km}$ south of the Galapagos spreading center, East $\mathrm{Pacific}$ Ocean, is $\mathrm{FeO}^{*}$ - and $\mathrm{TiO}_{2}$-rich $(\sim 13.3$ and 1.85 wt. $\%$, respectively, $\mathrm{FeO}^{*}$ expressing the total $\mathrm{Fe}$ content) oceanic tholeiite containing groundmass clinopyroxene $\left(\mathrm{Fs}_{16-35}\right)$, plagioclase $\left(\mathrm{An}_{60-70}\right)$, titaniferous magnetite, pyrrhotite, and interstitial material, much of which is altered but $\mathrm{SiO}_{2}$-rich where fresh. Trace-element abundances in these ferrobasalts $\left(\mathrm{FeO}^{*} / \mathrm{MgO}\right.$ 2.1) show low $\mathrm{Ni}$ contents (30 to $90 \mathrm{ppm}$ ), a depletion in light REE, and a negative Eu anomaly. Basalt recovered from Site 425, 62 $\mathrm{km}$ north of the spreading center, is high- $\mathrm{SiO}_{2}(51.5 \mathrm{wt} \%)$ and low$\mathrm{Na}_{2} \mathrm{O}(\sim 2.0$ wt $\%)$ oceanic tholeiite and is composed of phases similar to those of Site 424 ferrobasalt, except that clinopyroxene is richer in $\mathrm{MgO}\left(\mathrm{Fs}_{10-30}\right)$. Basalts at both sites are relatively fresh and free of notable hydrothermal alteration.

The ferrobasalts are compositionally similar to those previously reported from the region of the Galapagos spreading center, and are characteristic of a "normal" mid-oceanic ridge environment where substantial clinopyroxene and plagioclase (and minor olivine) fractionation occurred in light REE and LIL element-depleted parental magma. The Site 425 basalt, although fractionated, is substantially closer to primitive oceanic tholeiite than ferrobasalt and is probably the product of largely plagioclase and lesser olivine fractionation from primitive oceanic tholeiite magma.
\end{abstract}

\section{INTRODUCTION}

The crustal spreading axis in the region of the Galapagos Islands, Eastern Pacific Ocean, is a complex east-west-trending ocean ridge system extending eastward from the intersection of the Pacific, Cocos, and Nazca lithospheric plates at about $2^{\circ} \mathrm{N}$ and $102^{\circ} \mathrm{W}$ (Figure 1). As defined by transform faults, three major segments compose this spreading system: the CocosNazca rise, the Galapagos spreading center, and the Costa Rica rift. Drilling during Leg 54 was done along the central segment of the system, the Galapagos spreading center. This region is of special interest for its hydrothermal fields defined by $\mathrm{Fe}-\mathrm{Mn}$ oxide-encrusted sediment mounds (about $10 \mathrm{~m}$ high, $25 \mathrm{~m}$ across; Lonsdale, 1977); high heat flow (Sclater and Klitgord, 1973; Williams et al., 1974); and high water temperature $\left(\sim 15^{\circ} \mathrm{C}\right.$; Corliss and Ballard, 1977). Basaltic crust at the spreading center was an important objective of the drilling, for the characterization of this material is essential for a proper understanding of oceanic hydro- thermal activity, mineralization, and the formation of sediment mounds. Accordingly, we drilled and recovered basalt for study from two sites at the Galapagos spreading center.

\section{GENERAL DESCRIPTIONS}

Site 424 is located about $22 \mathrm{~km}$ south of the spreading center axis (Figure 1) near $0^{\circ} 35^{\prime} \mathrm{N}$ and $86^{\circ} 07^{\prime} \mathrm{W}$, at a depth of about 2700 meters of water. This site comprises four closely spaced drill holes (each about $300 \mathrm{~m}$ apart on a north-south line) designated Holes 424, 424A, $424 \mathrm{~B}$, and 424C. On the basis of magnetic anomalies, the crustal age there is about $0.60 \mathrm{~m}$.y.; attempts at $\mathrm{K}-\mathrm{Ar}$ dating were futile owing to excess $\mathrm{Ar}$ (E. H. McKee, USGS, written communication). Shipboard examinations and analyses of the rocks from the four holes revealed them to be relatively fresh aphyric ferrobasalt. Of the four holes, samples selected for postcruise study are from Hole 424, where drilling was carried out through a mound and where the deepest basalt penetration was achieved ( $45 \mathrm{~m}$ of basalt; $8.5 \mathrm{~m}$ of core 


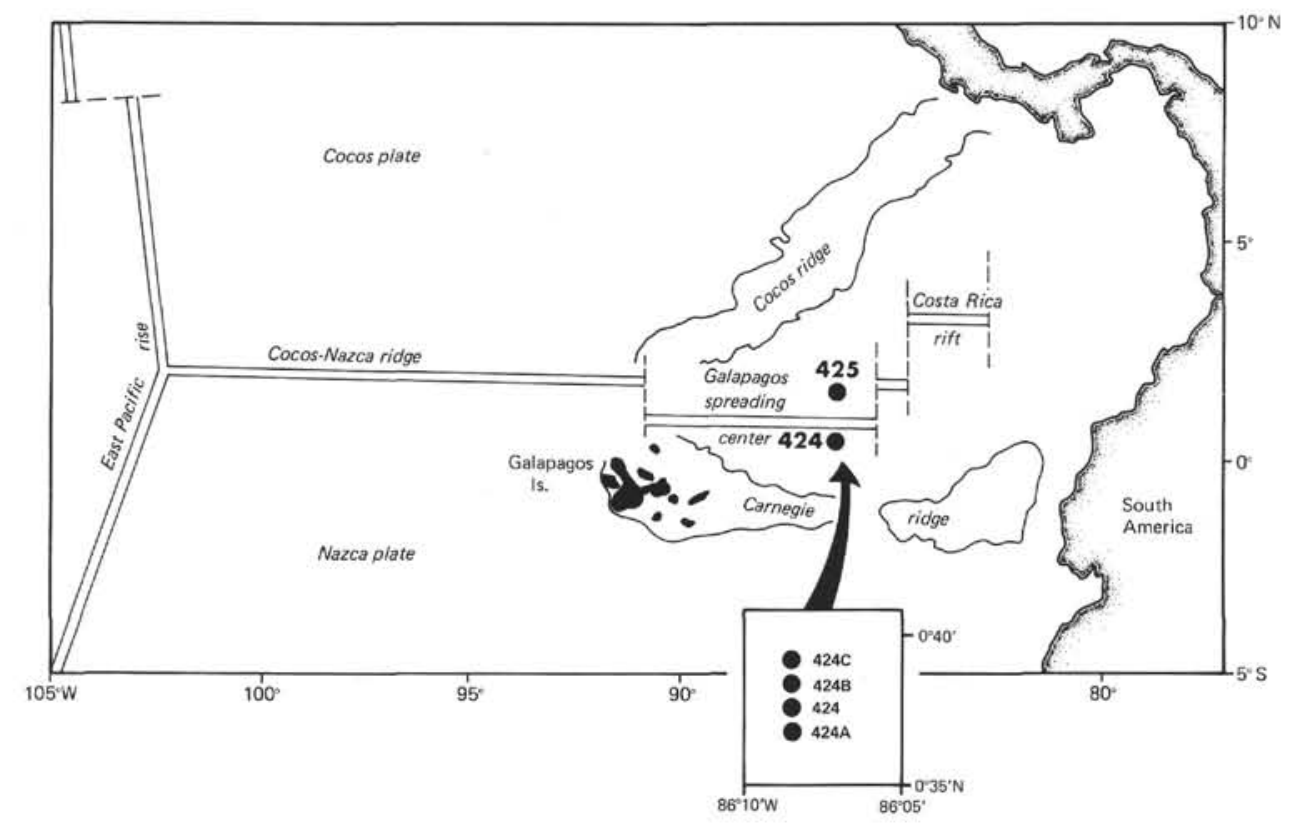

Figure 1. Index map showing locations of Sites 424 and 425 . Inset shows relative positions of the four holes drilled at Site 424.

recovery), and from off-mound Hole 424B (14.5 m of basalt; $3 \mathrm{~m}$ of core recovery).

Site 425 is located about $62 \mathrm{~km}$ north of the spreading center axis near $1^{\circ} 24^{\prime} \mathrm{N}$ and $86^{\circ} 04^{\prime} \mathrm{W}$ at a water depth of about 2850 meters (Figure 1). The crustal age here is about $1.8 \mathrm{~m} . y$. Basalt penetration was about 30 meters, and 5.6 meters of basalt core was recovered. Shipboard examination and analyses showed that the rock was relatively fresh aphanitic basalt, and compositionally more "normal" oceanic tholeiite.

In view of the potential genetic significance between the sediment mounds and underlying basement rock in the area of Site 424 (where hydrothermal fluids percolating through the basement could be responsible for mound development; Lonsdale, 1977), special attention was directed at the basalt from this region. Also, it was hoped that this study could contribute to the characterization and understanding of ferrobasalts. Therefore, this report presents the petrography, mineral chemistry, and the major element, trace element, and rare-earth element (REE) abundances for samples taken at relatively close intervals from Holes 424 and 424B. Similar studies, with the exception of analyses for REE, were made of three samples from Site 425 .

\section{ANALYTICAL PROCEDURES}

Whole-rock analyses were obtained by the following techniques. Silica was determined gravimetrically. Total $\mathrm{Fe}, \mathrm{Al}_{2} \mathrm{O}_{3}, \mathrm{MgO}, \mathrm{CaO}, \mathrm{Na}_{2} \mathrm{O}, \mathrm{K}_{2} \mathrm{O}, \mathrm{TiO}_{2}$, and $\mathrm{MnO}$ were determined by atomic absorption using calibration curves prepared from U.S. Geological Survey standard basalt, BCR-1. For determination of $\mathrm{P}_{2} \mathrm{O}_{5}$, an adaptation of the Molybdenum Blue spectrophotometric method was employed. Water was determined by ignition loss, but the amount of $\mathrm{Fe}$ oxidation was taken into account by $\mathrm{K}_{2} \mathrm{Cr}_{2} \mathrm{O}_{7}$ titration of ferrous iron in both the ignited and unignited sample.

The trace elements $\mathrm{Co}, \mathrm{Cr}, \mathrm{Sc}, \mathrm{Ni}, \mathrm{V}$, and REE for Site 424 were determined by instrumental neutron activation analyses; $\mathrm{Sr}$ plus all trace elements for Site 425 were obtained by atomic absorption. Mineral compositions were determined with an ARL-EMX-SM electron microprobe operated at $15 \mathrm{keV}$ accelerating voltage and 0.015 to $0.20 \mu \mathrm{A}$ sample current. Corrections for differential matrix effects were made following the procedures of Bence and Albee (1968) and Albee and Ray (1970).

\section{PETROGRAPHY}

All samples from Holes 424 and 424B have identical modal mineralogy of plagioclase, clinopyroxene, and oxides, but display a gradational textural range from: plagioclase microlites $(0.1 \mathrm{~mm})$ in hyalo-ophitic rocks (Figure $2 \mathrm{~A})$ to fine-grained intergranular rocks $(0.3$ to $0.5 \mathrm{~mm}$ ) with minor intersertal areas (Figure 2B) to moderately coarse grained $(1.0 \mathrm{~mm})$ subophitic rocks with some intersertal areas (Figure $2 \mathrm{C}$ ). In some rocks, the plagioclase and clinopyroxene have feathery variolitic relationships, and in the finer grained samples plagioclase laths are somewhat skeletal in form. Quartz was not observed optically, but microprobe analyses revealed free $\mathrm{SiO}_{2}$ in several samples as discrete grains and as micron-sized $\mathrm{SiO}_{2}$ concentrations in interstitial material.

Although material that was originally glass makes up an important part of these rocks, fresh glass is now rare. It often contains crystallites of plagioclase and pyroxene (Figure 3). As indicated by weak birefringence, most glass seems to be altered to clay(?) minerals. These intersertal areas of "glass" display substantial concentra- 

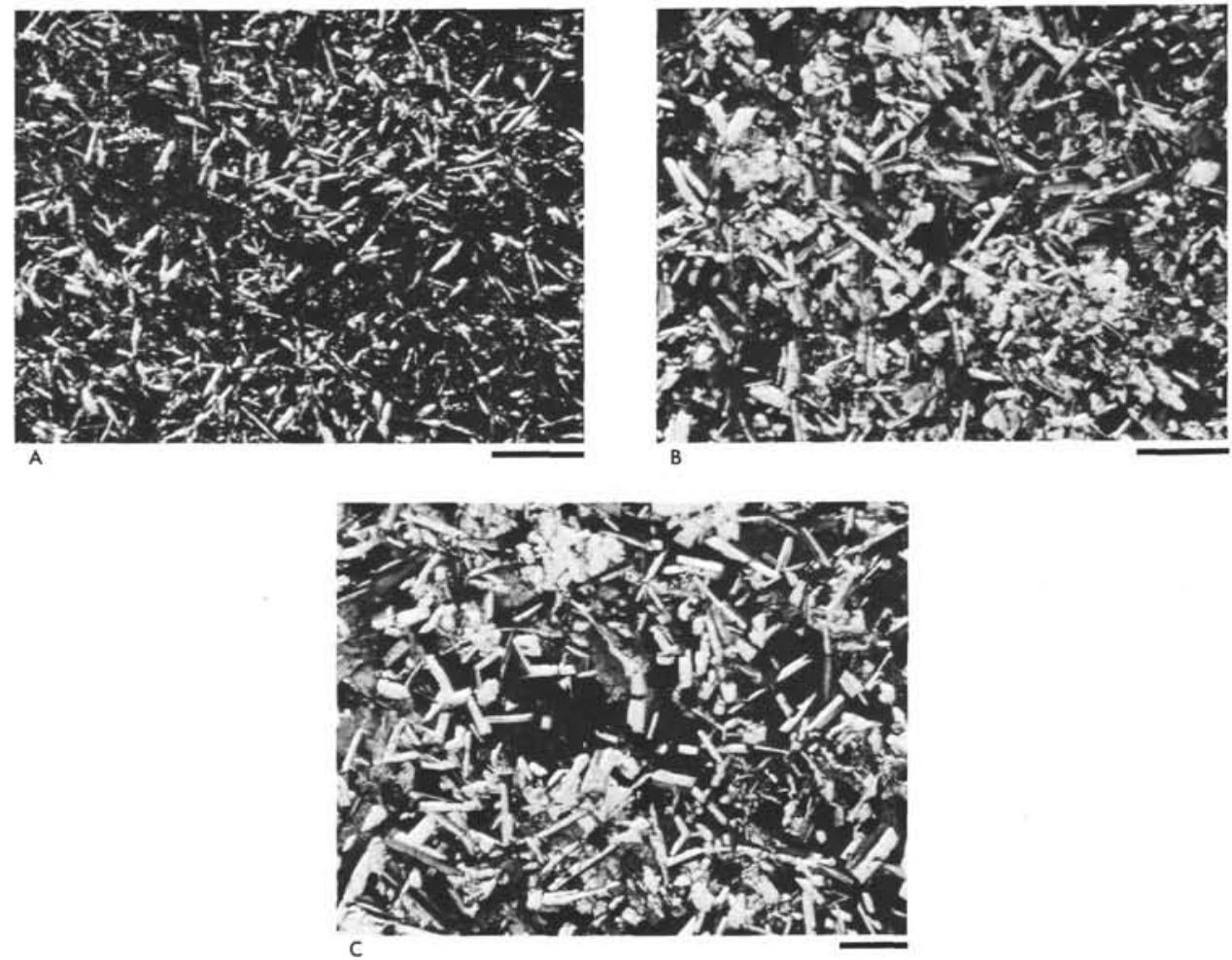

Figure 2. (A) Hyalo-ophitic texture in basalt sample from Section 424B-5-1 showing mainly plagioclase microlites and lesser clinopyroxene grains in a matrix that was originally glassy; (B) intergranular texture in basalt from Section 424-5-2; and (C) intergranular to subophitic texture in basalt from Section 424-6-2. Transmitted light, crossed nicols; scale bars equal $1 \mathrm{~mm}$.
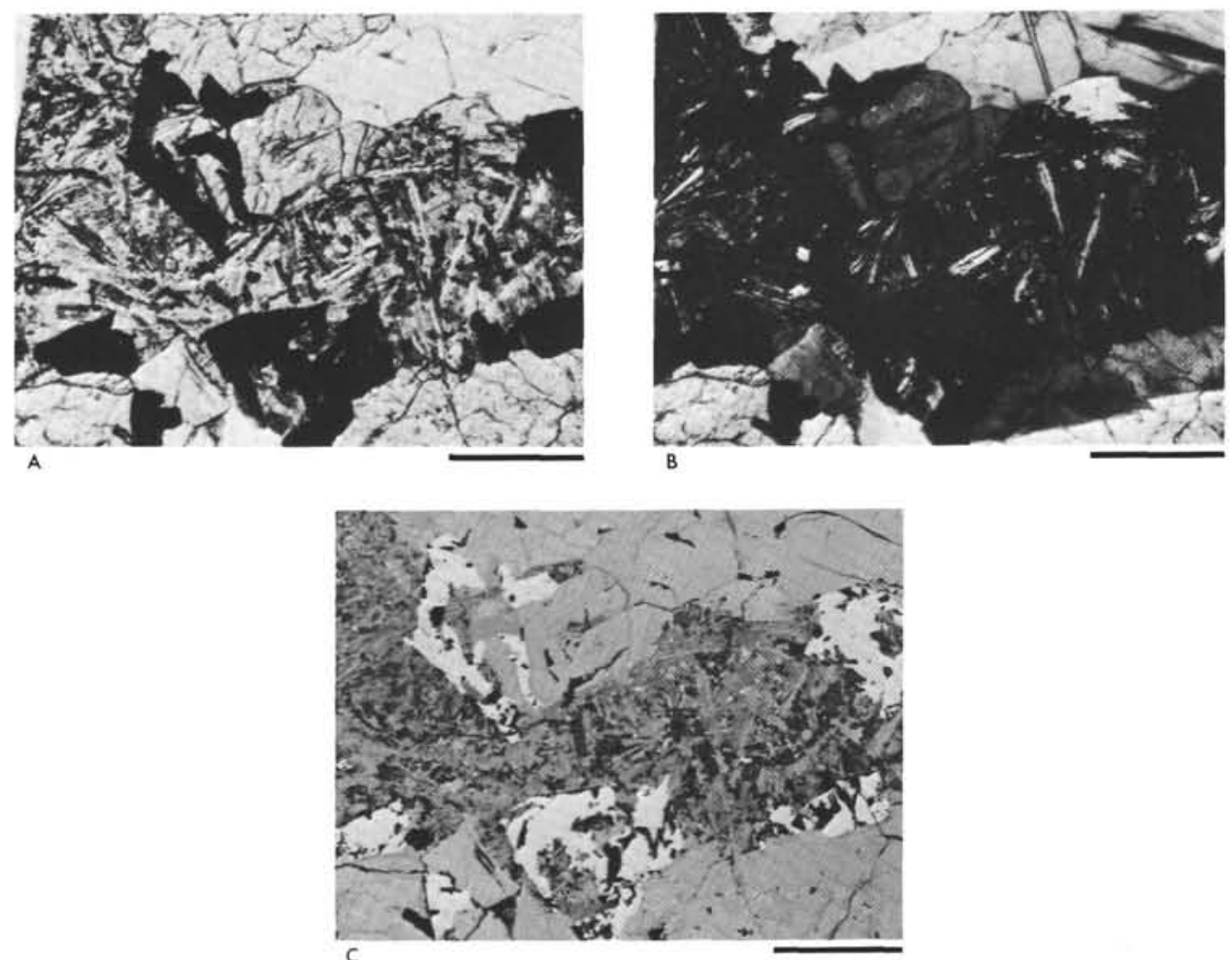

Figure 3. Interstitial area in basalt from Section 424-6-2 in (A) plane transmitted light; (B) transmitted light, crossed nicols; and (C) reflected light. Original interstitial glass contains skeletal crystals and is altered in part to clay-like material. Opaque phases are concentrated in these areas. Scale bars equal $0.2 \mathrm{~mm}$. 
tions of opaque minerals, mainly titaniferous magnetite, with minor sulfide minerals as well (Figure 4). In fact, the sulfides in Site 424 are spherules 1 to $3 \mu \mathrm{m}$ in diameter that are largely restricted to these intersertal areas; such occurrences seem to be characteristic of oceanic basalt (Mathez and Yeats, 1976; Czamanske and Moore, 1977). Nearly all the samples have some other minerals such as clays or zeolites filling vesicles.

The two Site 424 samples selected for microprobe analyses represent different aspects of the textural scheme: Sample 424-4-6, 112-116 cm, piece 3 is finegrained intergranular (Figure 5A) with some intersertal areas, and Sample 424-6-2,2-5 cm, piece 1A is moderately coarse grained subophitic (Figure 5B) with some plagioclase large enough to be considered microphenocrysts.

Samples from Site 425 have mineralogy and textures very similar to Site 424 rocks. Textures range from hyalo-ophitic with crystallites of plagioclase, to intergranular with small intersertal areas. Also, most of the areas that were once glassy now have weak birefringence and appear altered. The glassy areas also contain sulfides. Nearly all rocks have vesicles with secondary minerals, and microprobe examination revealed the presence of free $\mathrm{SiO}_{2}$ as grains and as micron-sized $\mathrm{SiO}_{2}$ concentrations in interstitial areas. Unlike Site 424 samples, however, some Site 425 rocks have phenocrysts, mainly of plagioclase, and, more rarely, of clinopyroxene as well (Figure 6B).

The Site 425 samples selected for microprobe analyses represent two different textures: Sample 425-7-2, $52-54 \mathrm{~cm}$, Piece 7A is intergranular (Figure 6A) and Sample $425-8-1,130-132 \mathrm{~cm}$, Piece 15 is porphyritic with glomerocrysts of plagioclase, minor clinopyroxene phenocrysts, and an intergranular and partly intersertal groundmass (Figure 6B).

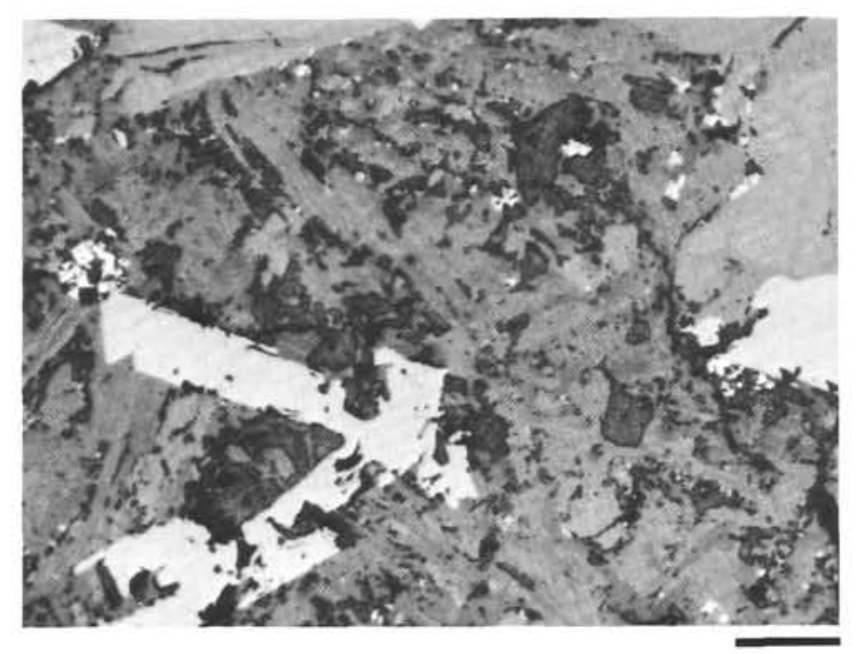

Figure 4. Sulfide spherule (far left) next to titaniferous magnetite within an interstitial formerly glassy area of basalt in Section 424-6-2. Reflected light; scale bar equals $0.2 \mathrm{~mm}$.
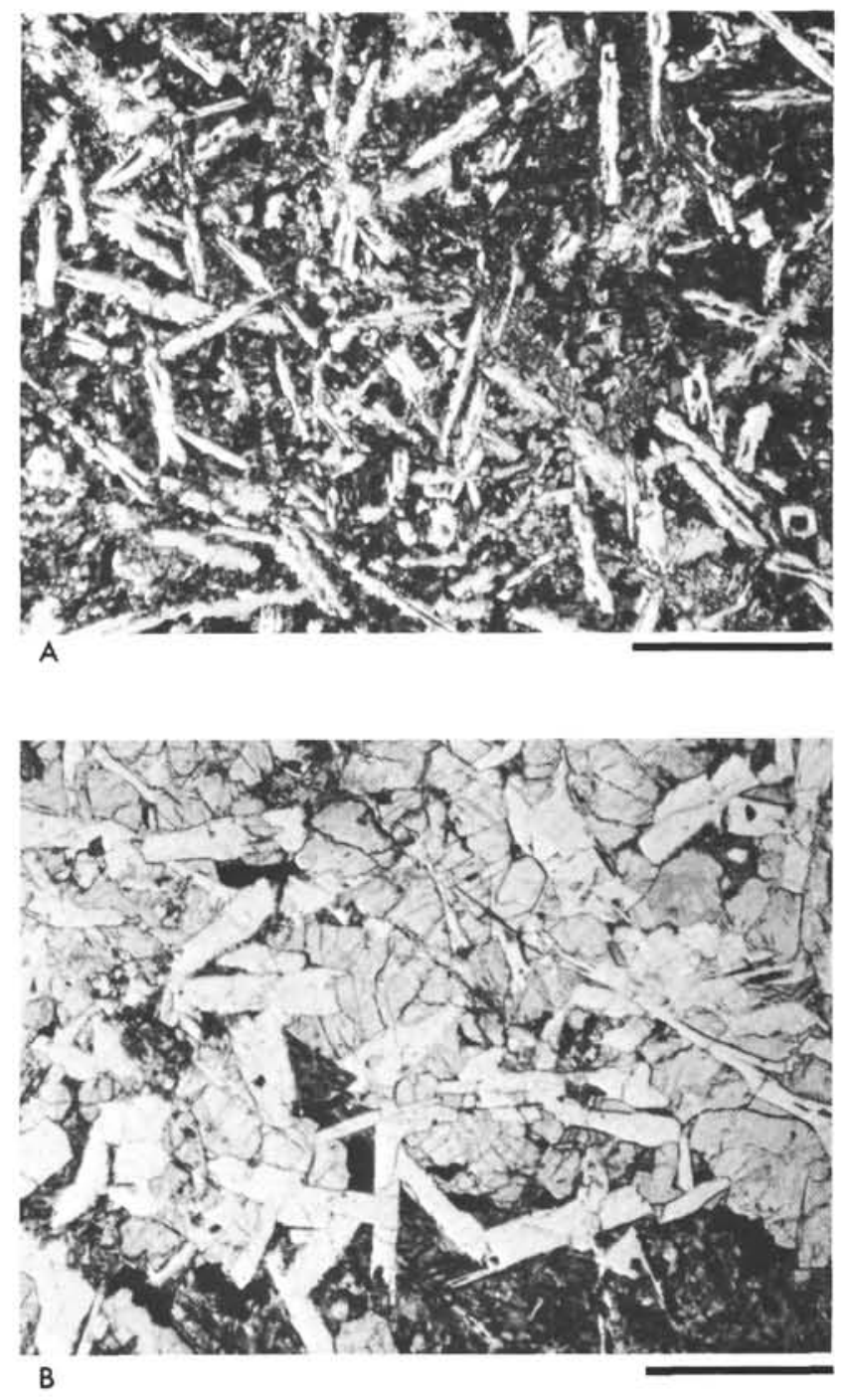

Figure 5. (A) Intergranular texture of plagioclase and clinopyroxene in basalt from Section 424-4-6, and (B) the subophitic texture of basalt from Section 424-6-2. Transmitted, plane-polarized light; scale bars equal $0.5 \mathrm{~mm}$.

\section{BULK COMPOSITION}

Whole-rock analyses and normative mineralogy of five samples from Hole 424, three samples from Hole 424B, and three from Hole 425 are presented in Table 1. Relative positions of the cores sampled for analyses are illustrated in Figure 7. Sampling was done on shipboard, and material was selected that would potentially provide as diverse a representation as possible.

\section{Holes 424 and 424B}

Because of the high total $\mathrm{FeO}^{*}$ contents $\left(\mathrm{FeO}^{*}=\right.$ $\mathrm{FeO}+0.9 \mathrm{Fe}_{2} \mathrm{O}_{3} \approx 13.3$ wt. \%) of each sample, all material recovered is designated clearly as ferrobasalt. Low $\mathrm{K}_{2} \mathrm{O}(\sim 0.07$ wt. $\%)$ and high $\mathrm{SiO}_{2}$ and normative quartz contents of these rocks further identify them as 

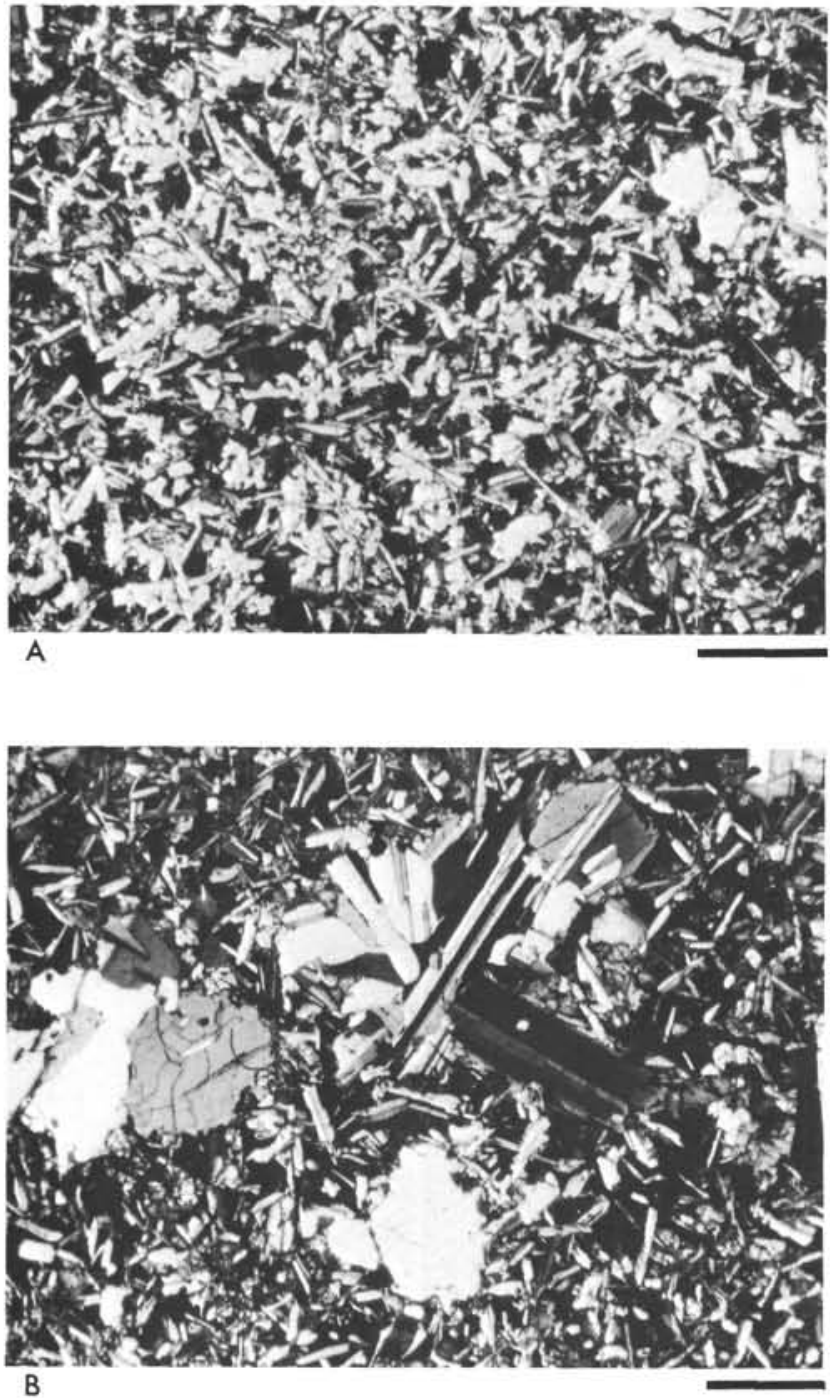

Figure 6. (A) Intergranular texture of plagioclase and clinopyroxene in basalt from Section 425-7-2, and (B) the porphyritic texture, phenocrysts of plagioclase and clinopyroxene, of basalt from Section 425-8-1. Transmitted light, crossed nicols; scale bars equal $1 \mathrm{~mm}$.

quartz tholeiites. Notable, too, are the relatively high $\mathrm{TiO}_{2}(\sim 1.85$ wt. $\%)$ and low $\mathrm{Al}_{2} \mathrm{O}_{3}(\sim 13.3$ wt. $\%)$ contents. These are all features diagnostic of other ferrobasalts (sometimes called FETI basalts in reference to high $\mathrm{Fe}$ and $\mathrm{Ti}$ contents [Melson et al., 1976]) dredged from the region of the Galapagos spreading center (Anderson et al., 1975; Schilling et al., 1976), and drilled from the nearby Peru basin (Kempe, 1976).

The low $\mathrm{Ni}$ (30 to $90 \mathrm{ppm})$ and Co (53 to $69 \mathrm{ppm})$ contents are compatible with the high $\mathrm{FeO}^{*} / \mathrm{MgO}$ ratios $(\sim 2.1)$, both values suggesting substantial fractionation of $\mathrm{Mg}$-rich olivine from a precursor magma. If $\mathrm{Cr}$ spinels were associated with such olivine, this could also account for the relatively low $\mathrm{Cr}(\sim 100 \mathrm{ppm})$ contents of the rock. High V abundances are compatible with the high $\mathrm{Ti}$ values; $\mathrm{V}$ is expected to accompany $\mathrm{Ti}$, especial- ly in the Fe- and Ti-oxide phases. All other traceelement abundances, such as the low $\mathrm{Sr}$ contents, are compatible with the composition of most mid-ocean ridge basalts (e.g., Kay and Hubbard, 1978).

The chondrite-normalized REE abundances are plotted on Figure 8. The trend is that of light REE depletion relative to chondrites and a negative europium anomaly. Similar REE concentrations have been shown for other ferrobasalts dredged and drilled from the Galapagos region (Figure 8). Relative to less-fractionated (i.e., lower $\mathrm{FeO}^{*}$ ) basalt of the East Pacific regions (e.g., Thompson et al., 1976) and to mid-ocean ridge basalt in general (e.g., Kay et al., 1970), there is substantial enrichment of all REE. As pointed out by Schilling et al. (1976), systematic increases of all REE abundances can accompany increasing $\mathrm{FeO}^{*}$ contents in basalt, where higher amounts of both $\mathrm{REE}$ and $\mathrm{FeO} *$ reflect greater degrees of fractionation from more primitive basaltic magmas.

The basalt compositions are similar throughout Holes 424 and 424B, showing virtually no differences in major- or trace-element abundances, except for Ni. The small variation in $\mathrm{Ni}$ concentrations may be due to a rare appearance of olivine in a few samples, although olivine was not observed optically during this study (shipboard examinations, however, did reveal the presence of rare olivine in a few samples). Similarly, there is essentially no horizontal change in composition between the two holes which are about 400 meters apart. Textural variations indicate that probably several lava flows make up material cored in each area but, clearly, all flows represent the same source magma.

\section{Site 425}

Basaltic samples at Site 425 have $\mathrm{FeO}^{*}$ contents similar to typical oceanic basalt ( $\sim 10$ wt. $\%$ ), but $\mathrm{SiO}_{2}$ contents are exceptionally high and $\mathrm{Na}_{2} \mathrm{O}$ and $\mathrm{TiO}_{2}$ contents very low compared with most oceanic tholeiite (e.g., Kay et al., 1970; Engel et al., 1965). The high normative-quartz content shows that these rocks are well within the quartz tholeiite basalt field.

Rocks having similar $\mathrm{FeO}^{*}$ and $\mathrm{SiO}_{2}$ contents have been dredged (Anderson et al., 1975; Schilling et al., 1976) from the Galapagos region and drilled (Kempe, 1976) from the Peru basin, but none is reported to be so depleted in $\mathrm{Na}_{2} \mathrm{O}$ as those described here. The less-fractionated nature (compared with Site 424 rocks) of Site 425 basalt applies also to very low $\mathrm{P}_{2} \mathrm{O}_{5}, \mathrm{Sr}$, and $\mathrm{Ba}$ in the three samples, and very low $\mathrm{K}_{2} \mathrm{O}$ in two of them. Trace-element analyses show less $\mathrm{V}$ and more $\mathrm{Cr}$ than the ferrobasalts; the higher $\mathrm{Cr}$ contents are compatible with these rocks displaying less fractionation than the ferrobasalt. Basalt with such high $\mathrm{SiO}_{2}$ and low largeion lithophile element contents are uncommon among oceanic tholeiites, but a few examples have been discovered through drilling in the Indian Ocean. Melson et al. (1976) referred to this basalt type as HISI.

The core displays some vertical variation. For example, the middle sample from Section 425-8-1 (Table 1, column 10), is higher in $\mathrm{Al}_{2} \mathrm{O}_{3}, \mathrm{CaO}$, and $\mathrm{K}_{2} \mathrm{O}$, and lower in $\mathrm{FeO}^{*}, \mathrm{MgO}, \mathrm{TiO}_{2}$, and $\mathrm{Na}_{2} \mathrm{O}$ than the other 
TABLE 1

Bulk Compositions (in wt. \%) and Molecular Norms of Basalt from Site 424 (Holes 424 and 424B) and Hole 425, Galapagos Spreading Center, East Pacific Ocean

\begin{tabular}{|c|c|c|c|c|c|c|c|c|c|c|c|}
\hline \multirow[b]{2}{*}{$\begin{array}{l}\text { Core-Section } \\
\text { Interval }(\mathrm{cm})\end{array}$} & \multicolumn{5}{|c|}{ Hole 424} & \multicolumn{3}{|c|}{ Hole 424B } & \multicolumn{3}{|c|}{ Hole 425} \\
\hline & $4-6,110$ & $5-1,70$ & $5-3,12$ & $6-1,60$ & $6-2,5$ & $5-1,25$ & $5-2,15$ & $6-1,70$ & $7-2,50$ & $8-1,130$ & $9-2,130$ \\
\hline $\mathrm{SiO}_{2}$ & 50.75 & 50.54 & 50.50 & 50.42 & 50.86 & 51.44 & 50.53 & 50.34 & 51.69 & 51.23 & 51.52 \\
\hline $\mathrm{TiO}_{2}$ & 1.87 & 1.87 & 1.80 & 1.88 & 1.86 & 1.85 & 1.88 & 1.83 & 1.12 & 0.74 & 0.96 \\
\hline $\mathrm{Al}_{2} \mathrm{O}_{3}$ & 13.26 & 13.20 & 13.16 & 13.10 & 13.24 & 12.80 & 13.30 & 13.24 & 14.40 & 15.80 & 14.15 \\
\hline $\mathrm{Fe}_{2} \mathrm{O}_{3}$ & 3.09 & 3.29 & 3.06 & 3.12 & 3.15 & 2.90 & 3.33 & 2.60 & 2.65 & 3.57 & 2.12 \\
\hline $\mathrm{FeO}$ & 10.57 & 10.39 & 10.27 & 10.34 & 10.38 & 10.68 & 10.23 & 10.91 & 8.14 & 6.11 & 8.31 \\
\hline $\mathrm{MnO}$ & 0.21 & 0.21 & 0.19 & 0.20 & 0.19 & 0.21 & 0.19 & 0.22 & 0.17 & 0.14 & 0.16 \\
\hline $\mathrm{MgO}$ & 6.49 & 6.40 & 6.55 & 6.43 & 6.13 & 6.30 & 6.50 & 6.25 & 7.30 & 6.80 & 7.78 \\
\hline $\mathrm{CaO}$ & 10.11 & 10.14 & 10.15 & 10.14 & 10.20 & 9.96 & 10.28 & 10.44 & 11.70 & 12.58 & 11.95 \\
\hline $\mathrm{Na}_{2} \mathrm{O}$ & 2.47 & 2.37 & 2.52 & 2.48 & 2.44 & 2.37 & 2.53 & 2.41 & 2.17 & 1.80 & 2.04 \\
\hline $\mathrm{K}_{2} \mathrm{O}$ & 0.06 & 0.06 & 0.05 & 0.06 & 0.09 & 0.08 & 0.08 & 0.08 & 0.04 & 0.31 & 0.04 \\
\hline $\mathrm{H}_{2} \mathrm{O}^{-}$ & 0.32 & 0.58 & 0.46 & 0.25 & 0.18 & 0.30 & 0.23 & 0.18 & 0.08 & 0.26 & 0.13 \\
\hline $\mathrm{H}_{2} \mathrm{O}^{+}$ & 0.67 & 0.87 & 0.80 & 0.93 & 0.67 & 0.77 & 0.62 & 0.86 & 0.68 & 0.50 & 0.78 \\
\hline $\mathrm{P}_{2} \mathrm{O}_{5}$ & 0.15 & 0.15 & 0.15 & 0.15 & 0.15 & 0.15 & 0.15 & 0.15 & 0.08 & 0.06 & 0.07 \\
\hline Total & 100.02 & 100.07 & 100.26 & 99.50 & 99.54 & 99.81 & 99.85 & 99.51 & 100.22 & 99.90 & 100.01 \\
\hline $\mathrm{FeO} * / \mathrm{MgO}$ & 2.06 & 2.09 & 1.99 & 2.05 & 2.16 & 2.11 & 2.03 & 2.12 & 1.44 & 1.37 & 1.31 \\
\hline $\mathrm{q}$ & 3.86 & 4.49 & 3.56 & 3.88 & 4.65 & 5.46 & 3.48 & 3.23 & 3.90 & 5.05 & 3.11 \\
\hline or & 0.37 & 0.37 & 0.31 & 0.37 & 0.55 & 0.49 & 0.49 & 0.49 & 0.24 & 1.87 & 0.24 \\
\hline$a b$ & 22.89 & 22.08 & 23.46 & 23.14 & 22.72 & 22.07 & 23.43 & 22.47 & 19.81 & 16.48 & 18.64 \\
\hline an & 25.72 & 26.15 & 25.35 & 25.40 & 25.83 & 24.95 & 25.48 & 26.03 & 29.93 & 34.80 & 29.86 \\
\hline di & 20.03 & 20.03 & 20.68 & 20.69 & 20.50 & 20.23 & 20.90 & 21.38 & 22.85 & 22.76 & 24.02 \\
\hline hy & 20.80 & 20.28 & 20.41 & 20.09 & 19.32 & 20.66 & 19.62 & 20.60 & 18.70 & 14.05 & 20.35 \\
\hline il & 2.68 & 2.70 & 2.59 & 2.72 & 2.68 & 2.67 & 2.70 & 2.64 & 1.58 & 1.05 & 1.36 \\
\hline $\mathrm{mt}$ & 3.33 & 3.56 & 3.31 & 3.38 & 3.41 & 3.14 & 3.59 & 2.82 & 2.81 & 3.80 & 2.25 \\
\hline ap & 0.32 & 0.32 & 0.32 & 0.32 & 0.32 & 0.32 & 0.32 & 0.32 & 0.17 & 0.12 & 0.14 \\
\hline $\mathrm{Ba}(\mathrm{ppm})$ & & & & & & & & & $<18$ & $<18$ & $<18$ \\
\hline $\mathrm{Sr}$ & 80 & 80 & 80 & 80 & 80 & 80 & 80 & 80 & 60 & 60 & 60 \\
\hline Co & 55 & 56 & 53 & 64 & 64 & 59 & 69 & 56 & 37 & 36 & 41 \\
\hline $\mathrm{Cr}$ & 102 & 101 & 99 & 103 & 104 & 105 & 105 & 110 & 223 & 260 & 218 \\
\hline $\mathrm{Cu}$ & & & & & & & & & 91 & 77 & 89 \\
\hline $\mathrm{Sc}$ & 48 & 48 & 48 & 48 & 47 & 49 & 49 & 49 & & & \\
\hline $\mathrm{Ni}$ & 80 & 70 & 30 & 90 & 40 & 70 & 40 & 50 & 57 & 64 & 71 \\
\hline V & 451 & 440 & 447 & 443 & 435 & 438 & 421 & 446 & 336 & 268 & 350 \\
\hline $\mathrm{Zn}$ & & & & & & & & & 90 & 63 & 88 \\
\hline $\mathrm{La}$ & 3.5 & 3.5 & 3.4 & 3.5 & 3.4 & 3.4 & 3.4 & 3.5 & & & \\
\hline $\mathrm{Ce}$ & 15 & 14 & 15 & 14 & 15 & 14 & 15 & 14 & & & \\
\hline $\mathrm{Nd}$ & 8 & 11 & 15 & 12 & 13 & 18 & 10 & 14 & & & \\
\hline $\mathrm{Sm}$ & 4.7 & 4.5 & 4.6 & 4.5 & 4.6 & 4.5 & 4.6 & 4.5 & & & \\
\hline $\mathrm{Eu}$ & 1.52 & 1.54 & 1.50 & 1.53 & 1.58 & 1.57 & 1.52 & 1.56 & & & \\
\hline $\mathrm{Tb}$ & 1.09 & 1.06 & 0.98 & 1.11 & 1.15 & 1.07 & 1.08 & 1.08 & & & \\
\hline Dy & 8.1 & 7.7 & 8.0 & 7.9 & 8.3 & 8.0 & 8.1 & 8.0 & & & \\
\hline $\mathrm{Yb}$ & 5.0 & 5.0 & 4.8 & 4.9 & 4.9 & 4.9 & 4.9 & 5.1 & & & \\
\hline $\mathrm{Lu}$ & 0.76 & 0.76 & 0.73 & 0.74 & 0.75 & 0.75 & 0.77 & 0.76 & & & \\
\hline $\mathrm{Hf}$ & 3.2 & 3.1 & 3.1 & 3.2 & 3.3 & 3.3 & 3.3 & 3.1 & & & \\
\hline
\end{tabular}

two Hole $\mathbf{4 2 5}$ samples. This sample is plagioclase-phyric and its difference in composition relative to the other two can be explained easily (except for $\mathrm{K}_{2} \mathrm{O}$ ) by the addition of An-rich plagioclase phenocrysts into a magma identical to the other two samples (i.e., $\mathrm{Ca}$ and $\mathrm{Al}$ higher in phyric rock; $\mathrm{Fe}, \mathrm{Mg}, \mathrm{Na}$, and $\mathrm{Ti}$ lower). The higher $\mathrm{K}_{2} \mathrm{O}$ content might be due to a contribution from secondary mineralization in the form of celadonite or smectite, in spite of the relatively moderate water content. (Shipboard descriptions pointed out a somewhat altered aspect of the core fragment from which the sample was taken.)

As at Site 424, the textures of the samples here show enough variation to indicate several discrete flows, but all are essentially identical in composition and were probably derived from the same source. Only vertical 

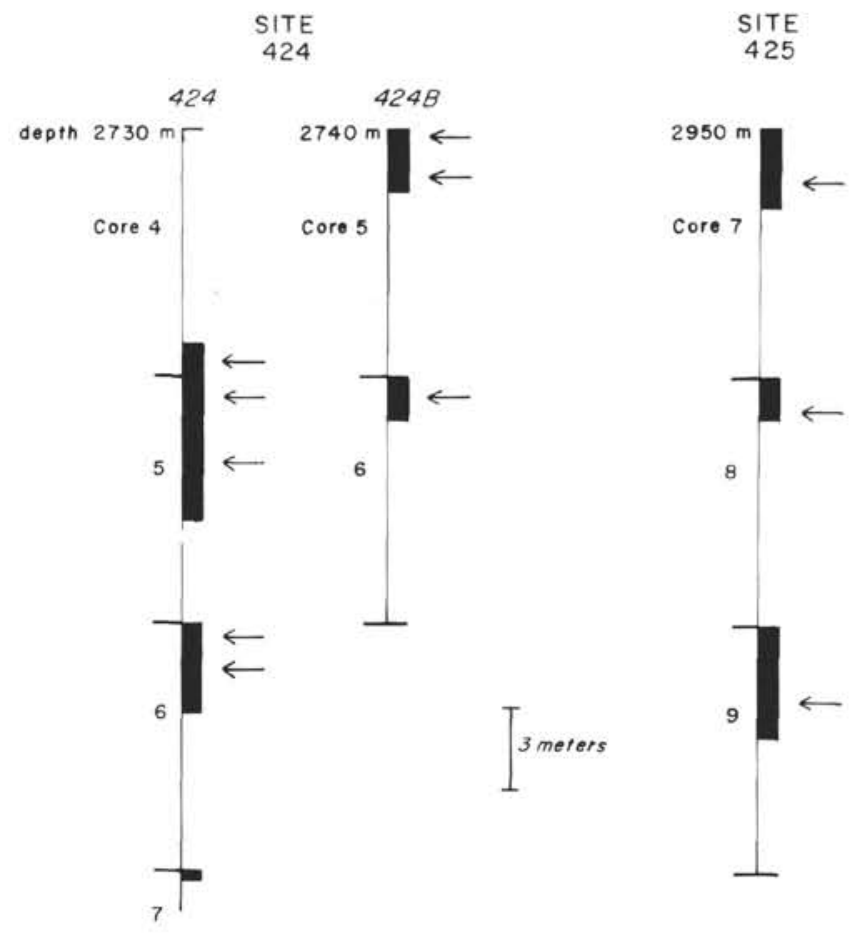

Figure 7. Relative core positions (arrows) of samples selected for whole-rock analyses. Shaded areas represent recovered rock; voids are not necessarily proportional to the amount of material missing (not recovered) from sections.

movement of early formed plagioclase and some minor alteration seem to have affected bulk composition.

\section{MINERALOGY}

\section{Clinopyroxene}

Representative point analyses of pyroxene grains are listed in Table 2, and intragrain and intergrain compositional variations are illustrated on Figure 9. Crystallization trends favor increasing $\mathrm{FeO}^{*}$ and decreasing $\mathrm{CaO}$ contents, characteristic of tholeiitic basalts (Fodor et al., 1975). However, there are strong tendencies for groundmass pyroxene in all samples to approach pigeonite compositions, filling in the miscibility gap between high- and low-Ca pyroxene. This is possibly because of rapid cooling and crystallization, although the subophitic sample curiously demonstrates this crystallization trend, too. Alternatively, the pyroxenes may have exsolved submicron-sized, low-Ca lamellae not resolvable by the electron probe.

The Fe-rich composition of the Site 424 samples shows up well in the pyroxene analyses plotted on Figure 9. The lowest Fs content is about 16 mole per cent, compared with some groundmass pyroxenes in Site 425 basalt having $\mathrm{Fs}_{10}$ compositions. The pyroxene phenocrysts in the phyric Site 425 sample are the most $\mathrm{Mg}$ - and $\mathrm{Cr}$-rich pyroxene observed, although there is compositional overlap with coexisting groundmass grains. The minor-element abundances in groundmass

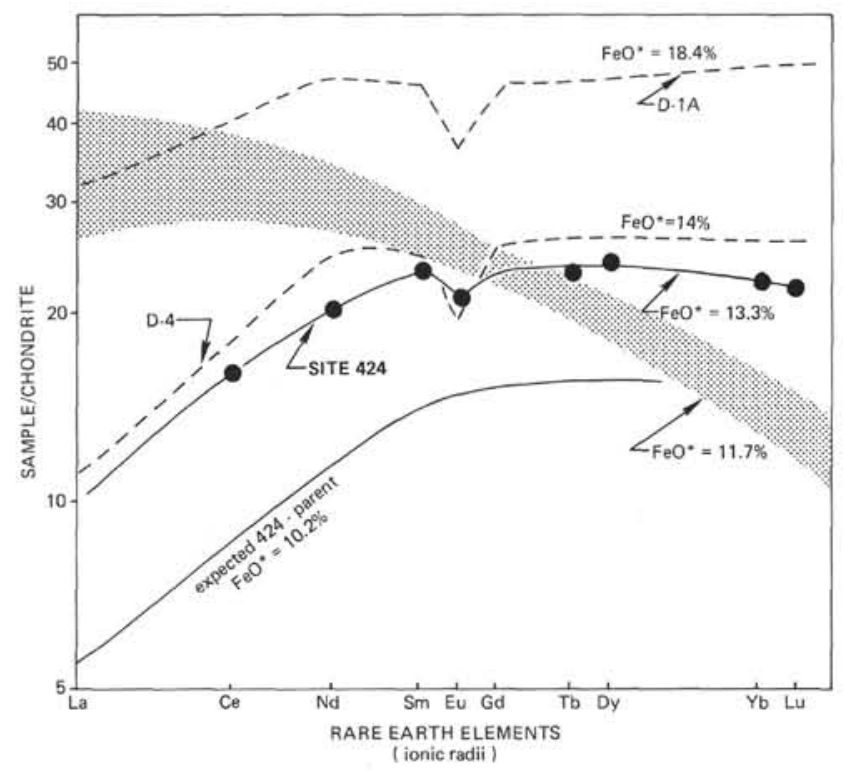

Figure 8. Chondrite-normalized rare-earth patterns for Site 424 FETI basalts (average of eight samples; solid line). Dashed lines represent patterns for other ferrobasalts from the Galapagos spreading center (Schilling et al., 1976). $\mathrm{FeO} *$ values are given for each pattern to illustrate the increasing $\mathrm{FeO} *$ with increasing absolute REE abundances. For comparison with plume-derived ferrobasalt (i.e., formed in a contrasting tectonic environment), the shaded area shows the range for Site 214 and 216 ferrobasalts from the Ninety east Ridge, Indian Ocean (Berkley, 1977). Normalized abundances were plotted versus REE ionic radii (VI coordinated), because ionic radii represent a more meaningful chemical parameter in fractionation processes compared to REE atomic number.

pyroxenes vary in accordance with decreasing $\mathrm{FeO}^{*}$ and increasing $\mathrm{CaO}$. Most notable is the decrease in $\mathrm{Al}$ which may reflect the competition for this element during simultaneous crystallization of pyroxene and plagioclase. The lower $\mathrm{Al}_{2} \mathrm{O}_{3}$ content of the pyroxene phenocrysts in the sample from Section 425-8-1 compared with coexisting groundmass pyroxene may indicate decreasing silica activity in the magma during the interim from phenocryst formation to groundmass crystallization.

\section{Plagioclase}

Representative point analyses of plagioclase are listed in Table 3, and intragrain and intergrain compositional variations are illustrated on Figure 10. Plagioclase in the Site 424 ferrobasalts is labradorite in composition, with the exception of some microphenocrysts in the subophitic sample that are zoned into the bytownite field. Groundmass plagioclase in the Site 425 basalt is compositionally zoned from calcic labradorite to sodic bytownite, and the phenocrysts of Section 425-8-1 are exceedingly rich in $\mathrm{CaO}\left(\mathrm{An}_{90}\right)$. 
TABLE 2

Representative Compositions of Clinopyroxene Phenocrysts (p) and Groundmass Grains (g) in Basalt from Sites 424 and 425, Galapagos Spreading Center, East Pacific Ocean (in wt. \%)

\begin{tabular}{|c|c|c|c|c|c|c|c|c|c|}
\hline \multirow{3}{*}{ Core-Section } & \multicolumn{4}{|c|}{ Hole 424} & \multicolumn{5}{|c|}{ Hole 425} \\
\hline & \multicolumn{2}{|c|}{$4-6$} & \multicolumn{2}{|c|}{$6-2$} & \multicolumn{2}{|c|}{$7-2$} & \multicolumn{3}{|c|}{$8-1$} \\
\hline & $\mathrm{g}$ & $\mathrm{g}$ & g & B & $\mathrm{g}$ & $g$ & p & g & g \\
\hline $\mathrm{SiO}_{2}$ & 49.0 & 49.4 & 51.4 & 52.8 & 51.8 & $\$ 2.4$ & 52.9 & 52.1 & 50.5 \\
\hline $\mathrm{TiO}_{2}$ & 1.3 & 1.3 & 0.90 & 0.47 & 0.53 & 0.42 & 0.22 & 0.57 & 0.56 \\
\hline $\mathrm{Al}_{2} \mathrm{O}_{3}$ & 3.6 & 2.2 & 2.9 & 1.1 & 2.6 & 1.8 & 2.1 & 2.7 & 1.7 \\
\hline $\mathrm{Cr}_{2} \mathrm{O}_{3}$ & 0.09 & 0.01 & 0.09 & 0.02 & 0.02 & 0.02 & 0.63 & 0.06 & 0.05 \\
\hline $\mathrm{FeO}$ & 13.5 & 20.4 & 9.9 & 14.5 & 9.2 & 11.0 & 4.7 & 8.3 & 17.2 \\
\hline $\mathrm{MnO}$ & 0.27 & 0.42 & 0.19 & 0.33 & 0.33 & 0.25 & 0.15 & 0.18 & 0.42 \\
\hline $\mathrm{MgO}$ & 13.5 & 13.2 & 16.0 & 18.9 & 17.4 & 19.8 & 18.5 & 17.9 & 16.3 \\
\hline $\mathrm{CaO}$ & 18,3 & 13.2 & 18.7 & 11.8 & 17.1 & 13.2 & 19.9 & 18.2 & 12.3 \\
\hline $\mathrm{Na}_{2} \mathrm{O}$ & 0.24 & 0.19 & 0.24 & 0.12 & 0.15 & 0.13 & 0.17 & 0.13 & 0.15 \\
\hline Total & 99.80 & 100.32 & 100.32 & 100.04 & 99.13 & 99.02 & 99.27 & 100.14 & 99.18 \\
\hline \multicolumn{10}{|c|}{ Number of ions on the basis of 6 oxygens } \\
\hline $\mathrm{Si}$ & 1.862 & 1.899 & 1.904 & 1.960 & 1.926 & 1.943 & 1.939 & 1.914 & 1.927 \\
\hline $\mathrm{Al}^{\mathrm{iv}}$ & 0.138 & 0.100 & 0.096 & 0.040 & 0.074 & 0.057 & 0.061 & 0.086 & 0.073 \\
\hline $\mathrm{Al}^{\mathrm{vi}}$ & 0.023 & - & 0.031 & 0.008 & 0.040 & 0.022 & 0.030 & 0.031 & 0.003 \\
\hline $\mathrm{Ti}$ & 0.037 & 0.038 & 0.025 & 0.013 & 0.015 & 0.012 & 0.006 & 0.016 & 0.016 \\
\hline $\mathrm{Cr}$ & 0.003 & - & 0.003 & 0.001 & 0.001 & 0.001 & 0.018 & 0.002 & 0.002 \\
\hline $\mathrm{Fe}$ & 0.429 & 0.656 & 0.307 & 0.450 & 0.286 & 0.341 & 0.144 & 0.255 & 0.549 \\
\hline Mn & 0.009 & 0.014 & 0.006 & 0.010 & 0.010 & 0.008 & 0.005 & 0.006 & 0.014 \\
\hline Mg & 0.765 & 0.756 & 0.884 & 1.046 & 0.964 & 1.094 & 1.011 & 0.980 & 0.927 \\
\hline $\mathrm{Ca}$ & 0.745 & 0.544 & 0.742 & 0.469 & 0.681 & 0.524 & 0.781 & 0.716 & 0.503 \\
\hline $\mathrm{Na}$ & 0.018 & 0.014 & 0.017 & 0.009 & 0.011 & 0.009 & 0.012 & 0.009 & 0.011 \\
\hline Z & 2.000 & 1.999 & 2.000 & 2.000 & 2.000 & 2.000 & 2.000 & 2.000 & 2.000 \\
\hline$X Y$ & $\underline{2.029}$ & $\underline{2.022}$ & $\underline{2.015}$ & 2.006 & 2.008 & $\underline{2.011}$ & 2.007 & $\underline{2.015}$ & 2.025 \\
\hline Total & 4.029 & 4.021 & 4.015 & 4.006 & 4.008 & 4.011 & 4.007 & 4.015 & 4.025 \\
\hline \multicolumn{10}{|c|}{ Molecular end members } \\
\hline Fs & 22.1 & 33.5 & 15.9 & 22.9 & 14.8 & 17.4 & 7.4 & 13.1 & 27.7 \\
\hline En & 39.5 & 38.7 & 45.7 & 53.2 & 49.9 & 55.8 & 52.2 & 50.2 & 46.9 \\
\hline Wo & 38.4 & 27.8 & 38.4 & 23.9 & 35.3 & 26.8 & 40.4 & 36.7 & 25.4 \\
\hline
\end{tabular}

As is characteristic of intermediate and calcic plagioclase of tholeiitic basalt, $\mathrm{K}$ is virtually absent (Keil et al., 1972). Also, as expected, higher $\mathrm{FeO}^{*}$ is present in the groundmass plagioclase of the ferrobasalts than in that of Site 425 basalt.

\section{Intersertal and Interstitial Material}

Representative point analyses of material intersertal and interstitial to plagioclase groundmass grains are presented in Table 4 . These compositions presumably represent the composition of the residual trapped liquids of original magma that are still fresh enough for electron probe analysis; most of the original glass appears to be partially altered and readily volatilizes under the electron beam. The intersertal and interstitial material in rocks of both sites is $\mathrm{SiO}_{2}$-rich and has varying amounts of $\mathrm{Al}_{2} \mathrm{O}_{3}$ and alkalis. One point analysis is that of essentially pure $\mathrm{SiO}_{2}$ (Table 4, column 6). In keeping with the tholeiitic nature of these Galapagos samples, no K-enrichment occurred during final crystallization and cooling.

\section{Opaque Oxides}

In spite of the greater amount of $\mathrm{FeO}^{*}$ in the Site 424 samples, the titaniferous magnetite does not contain significantly different $\mathrm{FeO}^{*}$ and $\mathrm{TiO}_{2}$ from those in Site 425 samples (Table 5). In fact, the overall composition of the oxides, which have 60 to 65 mole per cent ulvospinel content, is like those found in other oceanic tholeiites (e.g., Mazullo et al., 1976; Fodor et al., 1977).
Similarly, the $\mathrm{V}_{2} \mathrm{O}_{3}$ content in the oxide of the ferrobasalt does not reflect the higher $\mathrm{V}$ concentration in the whole rock. Apparently, the higher $\mathrm{FeO}^{*}, \mathrm{TiO}_{2}$, and $\mathrm{V}$ contents in the ferrobasalts are expressed by a greater modal percentage of oxides relative to the Site 425 samples. A modal analysis (1000 points) of two samples proved this: Section 424-4-6 has 5.8 volume per cent oxides, whereas Section $425-7-2$ has 3.4 volume per cent.

\section{Sulfides}

Sulfide grains are present in only trace amounts in all of the basalts examined and are usually less than $5 \mu \mathrm{m}$ in size. In the ferrobasalts, sulfides range in composition from nearly pure pyrrhotite, to pyrrhotite with minor $\mathrm{Cu}$ to substantial $\mathrm{Cu}$ contents ( $\sim 24$ wt. \%) (Table 6). Pyrite and $\mathrm{Cu}$-rich pyrrhotite were observed in the Site 425 basalts. In addition to the one analysis of a sulfide grain in a Site 425 basalt presented in Table 6, other grains were found to have 16 and 24 weight per cent $\mathrm{Cu}$ and $\leq 1.0$ weight per cent $\mathrm{Ni}$; small grain sizes, however, preclude summations of their analyses to near 100 weight per cent.

\section{DISCUSSION AND CONCLUSIONS}

The ferrobasalts of the Galapagos Spreading Center, Site 424 , are remarkably uniform in major- and traceelement compositions, both vertically (over $40 \mathrm{~m}$ ) and horizontally $(\sim 400 \mathrm{~m})$. Since compositionally similar ferrobasalt is present at both mound and nonmound holes (Holes 424 and 424B, respectively), little information can be extracted regarding the role of basement rock composition in the formation of the sediment mounds in the Galapagos hydrothermal field. These Fe-Mn-oxide encrusted mounds are believed to have originated over fault zones (structurally controlled), where sea water is transformed into hydrothermal fluid during its descent and passage in the fractured basaltic basement (Lonsdale, 1977). The petrologic results show only that a particular rock composition is no assurance of mound development, and that based on the freshness of these rocks, the upper-most basement, where drilled, had little to do with mound development.

Defining hydrothermal mineralization is a key objective of drilling in the Galapagos region. There is good evidence that hydrothermal solutions at spreading ridges are the cause of substantial $\mathrm{Fe}-\mathrm{Cu}$-sulfide mineralization (Bonatti et al., 1976; Rona, 1978). In these cases, veins of sulfides and evidence of hydrothermal alteration (e.g., greenschist facies metabasalt; Bonatti et al., 1976) are present. No such mineralization was noted in the Site 424 basalts and only traces were found in Site 425 basalts (Schrader et al., "Ore Petrology," this volume). The $\mathrm{Fe}$ - $\mathrm{Cu}$-sulfides in these basalts are much like those in typical magmatic systems in which primary sulfides are associated with immiscible silicate liquids. These sulfides commonly form as globules in glass (Desborough et al., 1968; Mathez and Yeats, 1976; Czamanske and Moore, 1977).

FETI basalts like those from Site 424 are found elsewhere in the Pacific Ocean at the East Pacific Rise and 


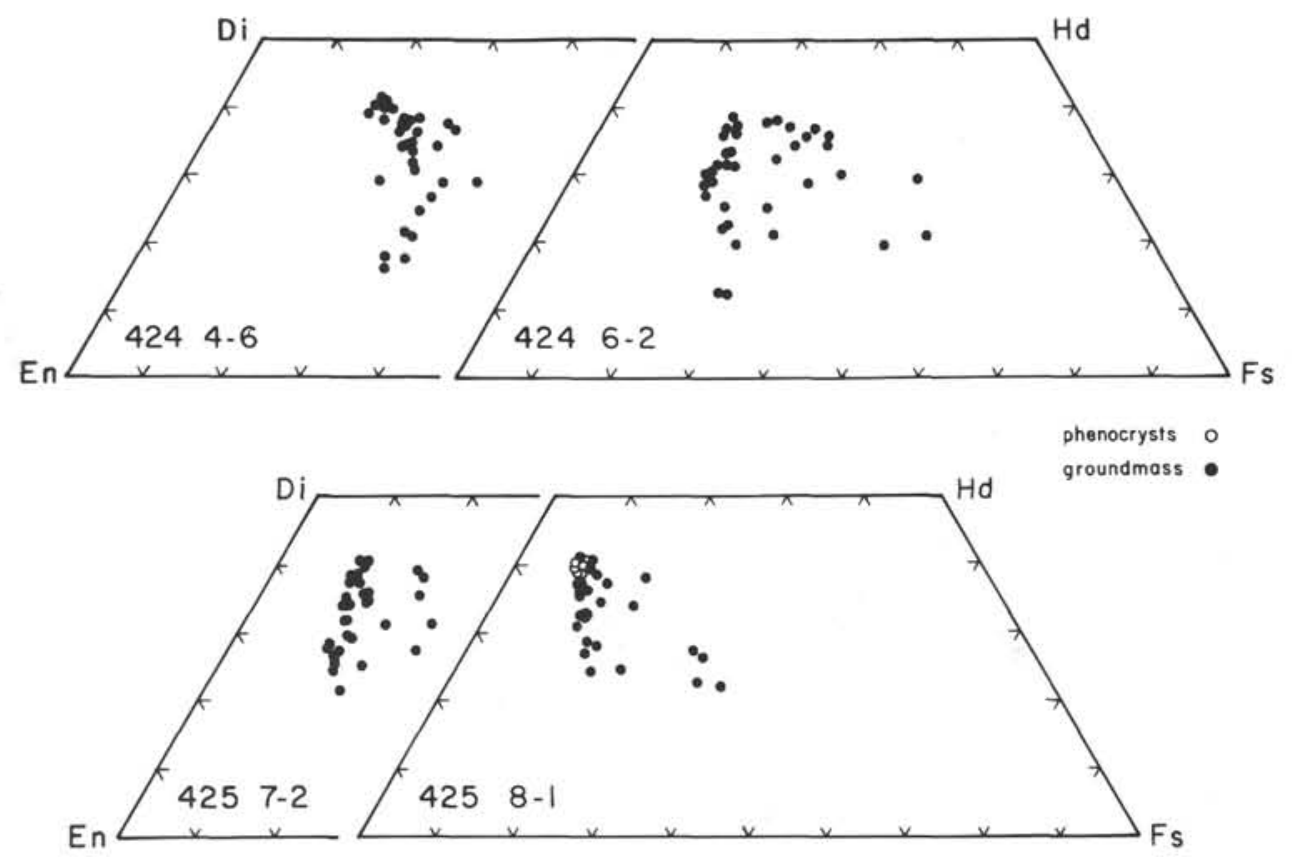

Figure 9. Pyroxene quadrilateral showing individual point analyses for clinopyroxene phenocrysts and groundmass in basalt from Sites 424 and 425 , plotted in terms of molecular end members enstatite ( $\mathrm{En}, \mathrm{MgSiO}_{3}$ ), ferrosilite ( $\left.\mathrm{Fs}, \mathrm{FeSiO}_{3}\right)$, diopside $\left[\mathrm{Di},(\mathrm{Ca}, \mathrm{Mg}) \mathrm{Si}_{2} \mathrm{O}_{6}\right]$, and hedenbergite $\left[\mathrm{Hd},(\mathrm{Fe}, \mathrm{Ca}) \mathrm{Si}_{2} \mathrm{O}_{6}\right]$.

TABLE 3

Representative Compositions of Plagioclase Phenocrysts (p), Microphenocrysts (m), and Groundmass Crystals (g) in Basalt from Sites 424 and 425, Galapagos Spreading Center, East Pacific Ocean (in wt. \%)

\begin{tabular}{|c|c|c|c|c|c|c|c|c|c|c|}
\hline \multirow{3}{*}{ Core-Section } & \multicolumn{5}{|c|}{ Hole 424} & \multicolumn{5}{|c|}{ Hole 425} \\
\hline & \multicolumn{2}{|c|}{$4-6$} & \multicolumn{3}{|c|}{$6-2$} & \multicolumn{2}{|c|}{$7-2$} & \multicolumn{3}{|c|}{$8-1$} \\
\hline & $\mathrm{g}$ & $\mathrm{g}$ & $\mathrm{m}$ & g & g & $\mathrm{g}$ & $\mathrm{g}$ & p & g & $\mathrm{g}$ \\
\hline $\mathrm{SiO}_{2}$ & 52.2 & 54.4 & 51.3 & 52.2 & 53.4 & 51.8 & 53.1 & 45.9 & 49.6 & 51.2 \\
\hline $\mathrm{Al}_{2} \mathrm{O}_{3}$ & 29.3 & 28.2 & 30.5 & 29.5 & 29.1 & 30.7 & 29.5 & 34.3 & 31.1 & 30.1 \\
\hline $\mathrm{FeO}$ & 0.99 & 1.1 & 0.74 & 1.2 & 0.81 & 0.59 & 0.78 & 0.41 & 0.50 & 0.67 \\
\hline $\mathrm{MgO}$ & 0.22 & 0.32 & 0.16 & 0.28 & 0.13 & 0.33 & 0.23 & 0.19 & 0.27 & 0.22 \\
\hline $\mathrm{CaO}$ & 12.9 & 12.3 & 14.1 & 13.1 & 12.2 & 14.4 & 13.1 & 17.4 & 15.2 & 13.6 \\
\hline $\mathrm{Na}_{2} \mathrm{O}$ & 3.7 & 4.2 & 3.3 & 3.5 & 4.1 & 2.9 & 3.8 & 1.1 & 2.5 & 3.3 \\
\hline $\mathrm{K}_{2} \mathrm{O}$ & 0.03 & 0.03 & 0.03 & 0.03 & 0.04 & 0.02 & 0.04 & 0.02 & 0.02 & 0.02 \\
\hline Total & 99.34 & 100.55 & 100.13 & 99.81 & 99.78 & 100.74 & 100.55 & 99.32 & 99.19 & 99.11 \\
\hline \multicolumn{11}{|c|}{ Number of ions on the basis of 32 oxygens } \\
\hline $\mathrm{Si}$ & 9.557 & 9.818 & 9.343 & 9.523 & 9.699 & 9.359 & 9.595 & 8.501 & 9.137 & 9.401 \\
\hline $\mathrm{Al}$ & 6.322 & 5.998 & 6.547 & 6.342 & 6.229 & 6.537 & 6.282 & 7.487 & 6.751 & 6.513 \\
\hline $\mathrm{Fe}$ & 0.152 & 0.166 & 0.113 & 0.183 & 0.123 & 0.089 & 0.118 & 0.063 & 0.077 & 0.103 \\
\hline $\mathrm{Mg}$ & 0.060 & 0.086 & 0.043 & 0.076 & 0.035 & 0.089 & 0.062 & 0.052 & 0.074 & 0.060 \\
\hline $\mathrm{Ca}$ & 2.530 & 2.378 & 2.751 & 2.560 & 2.374 & 2.787 & 2.536 & 3.452 & 3.000 & 2.675 \\
\hline $\mathrm{Na}$ & 1.313 & 1.469 & 1.165 & 1.238 & 1.444 & 1.016 & 1.331 & 0.395 & 0.893 & 1.175 \\
\hline $\mathrm{K}$ & 0.007 & 0.007 & 0.007 & 0.007 & 0.009 & 0.005 & 0.009 & 0.005 & 0.005 & 0.005 \\
\hline $\mathrm{Z}$ & 15.879 & 15.816 & 15.890 & 15.865 & 15.928 & 15.896 & 15.877 & 15.988 & 15.888 & 15.917 \\
\hline $\mathrm{XY}$ & 4.062 & 4.106 & 4.079 & 4.064 & 3.985 & 3.986 & 4.056 & 3.967 & 4.049 & 4.015 \\
\hline Total & 19.941 & 19.922 & 19.969 & 19.929 & 19.913 & 19.882 & 19.933 & 19.955 & 19.937 & 19.932 \\
\hline \multicolumn{11}{|c|}{ Molecular end members } \\
\hline An & 65.7 & 61.7 & 70.1 & 67.3 & 62.0 & 73.2 & 65.4 & 89.6 & 77.0 & 69.4 \\
\hline $\mathrm{Ab}$ & 34.1 & 38.1 & 29.7 & 32.5 & 37.8 & 26.7 & 34.4 & 10.3 & 22.9 & 30.5 \\
\hline Or & 0.2 & 0.2 & 0.2 & 0.2 & 0.2 & 0.1 & 0.2 & 0.1 & 0.1 & 0.1 \\
\hline
\end{tabular}




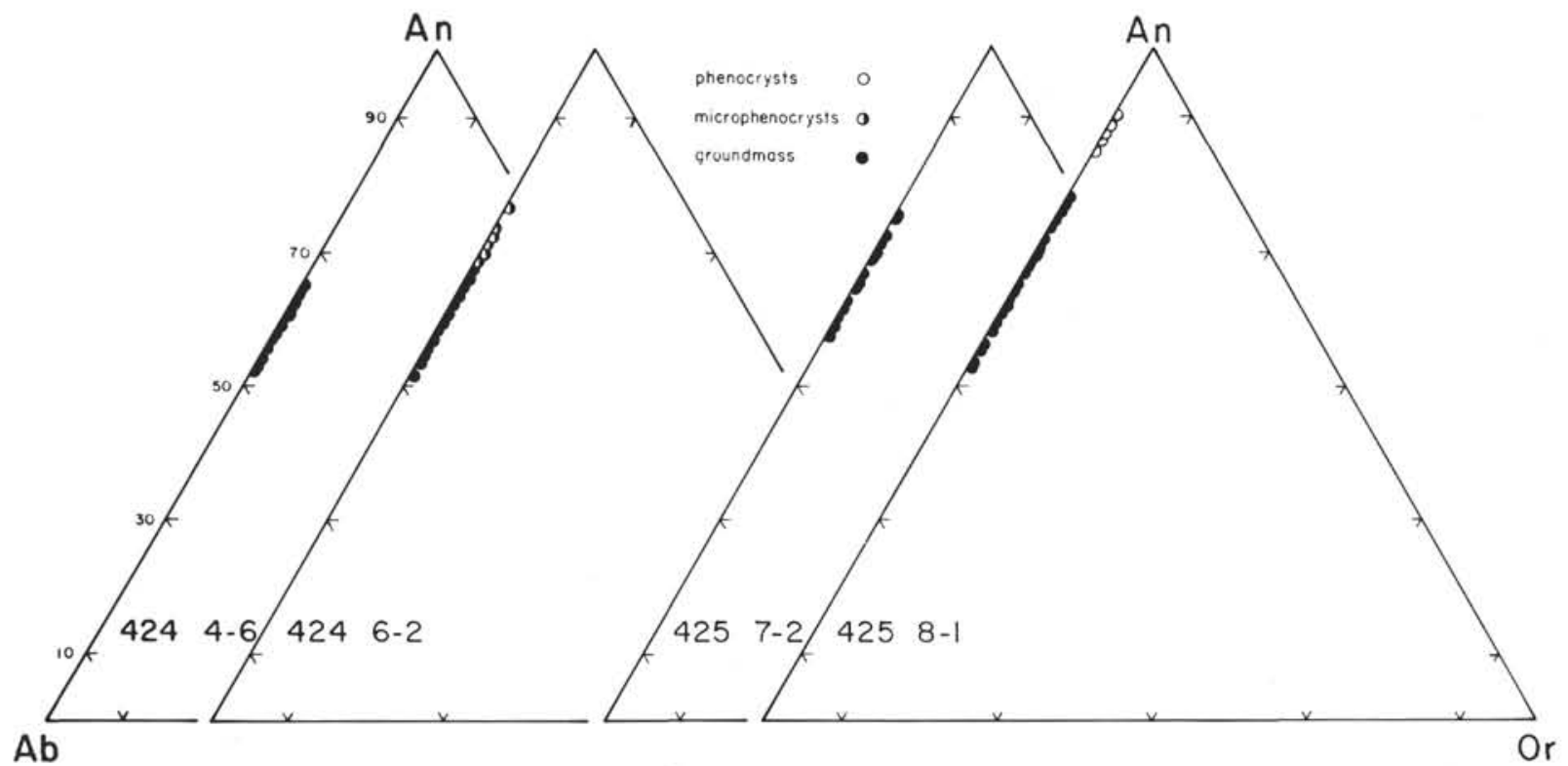

Figure 10. Feldspar ternary diagram showing individual point analyses for plagioclase phenocrysts, microphenocrysts, and groundmass grains in basalt from Sites 424 and 425, plotted in terms of molecular end members albite $\left(\mathrm{Ab}, \mathrm{NaAlSi}_{3} \mathrm{O}_{8}\right)$, orthoclase $\left(\mathrm{Or}, \mathrm{KAlSi}_{3} \mathrm{O}_{8}\right)$, and anorthite $(\mathrm{An}$, $\mathrm{CaAl}_{2} \mathrm{Si}_{2} \mathrm{O}_{8}$ ).

TABLE 4

Representative Compositions of $\mathrm{SiO}_{2}$-Rich Material within Interstitial and Intersertal Areas in Basalt from Sites 424 and 425, Galapagos Spreading Center, East Pacific Ocean (in wt\%)

\begin{tabular}{|c|c|c|c|c|c|c|c|}
\hline \multirow[b]{2}{*}{ Core-Section } & \multicolumn{5}{|c|}{ Hole 424} & \multicolumn{2}{|c|}{ Hole 425} \\
\hline & \multicolumn{3}{|c|}{$4-6$} & \multicolumn{2}{|c|}{$6-2$} & 7.2 & $8-1$ \\
\hline $\mathrm{SiO}_{2}$ & 76.3 & 70.7 & 78.7 & 75.9 & 72.6 & 98.6 & 82.2 \\
\hline $\mathrm{Al}_{2} \mathrm{O}_{3}$ & 14.2 & 13.9 & 11.4 & 16.6 & 13.6 & 0.09 & 4.2 \\
\hline $\mathrm{FeO}^{*}$ & 0.89 & 1.8 & 1.9 & 1.2 & 0.86 & 0.17 & 6.2 \\
\hline $\mathrm{MgO}$ & 0.25 & 0.77 & 0.48 & 0.10 & 0.08 & $<0.01$ & 0.78 \\
\hline $\mathrm{CaO}$ & 2.6 & 4.8 & 3.1 & 2.8 & 5.5 & $<0.01$ & 1.2 \\
\hline $\mathrm{Na}_{2} \mathrm{O}$ & 2.4 & 4.1 & 3.2 & 0.62 & 6.4 & $<0.01$ & 1.7 \\
\hline $\mathrm{K}_{2} \mathrm{O}$ & $\underline{0.04}$ & 0.07 & 0.06 & $\underline{0.01}$ & 0.06 & $\leq 0.01$ & 0.19 \\
\hline Total & 96.68 & 96.14 & 98.84 & 97.23 & 99.10 & 98.86 & 96.47 \\
\hline
\end{tabular}

the Juan de Fuca Ridge. Other FETI basalts occur in the Indian Ocean at the Ninetyeast Ridge and Mozambique Ridge (Berkley, 1977; Thompson et al., 1978). Although compositionally all of the ferrobasalts are more or less alike, details of their compositions vary according to their tectonic environments. Three locations are at spreading centers (Galapagos, East Pacific Rise, and Juan de Fuca Ridge), whereas the Indian Ocean FETI basalts occur along aseismic ridges. The Site 424 samples are members of the Fe-rich and light REEdepleted basalts (Figure 8) of the Galapagos Spreading Center that Schilling et al. (1976) described as characteristic of "normal ridge segments" and associated with material derived from a REE-depleted mantle source. The same holds true for the ferrobasalts from the Juan de Fuca Ridge (Kay et al., 1970) and the East Pacific Rise (Schilling and Bonatti, 1975). This is in contrast to the Fe-rich tholeiitic rocks of the nearby Galapagos Islands which are relatively enriched in light REE (Schill-
TABLE 5

Representative Compositions of Titaniferous Magnetite in Basalt from Sites 424 and 425, Galapagos Spreading Center, East Pacific Ocean (in wt. \%)

\begin{tabular}{|c|c|c|c|c|}
\hline \multirow[b]{2}{*}{ Core-Section } & \multicolumn{2}{|c|}{ Hole 424} & \multicolumn{2}{|c|}{ Hole 425} \\
\hline & $4-6$ & $6-2$ & $7-2$ & $8-1$ \\
\hline $\mathrm{SiO}_{2}$ & 0.16 & 0.20 & 0.26 & 0.30 \\
\hline $\mathrm{TiO}_{2}$ & 22.3 & 22.4 & 20.3 & 21.3 \\
\hline $\mathrm{Al}_{2} \mathrm{O}_{3}$ & 1.6 & 1.9 & 1.4 & 1.7 \\
\hline $\mathrm{Cr}_{2} \mathrm{O}_{3}$ & 0.02 & 0.03 & 0.11 & $<0.01$ \\
\hline $\mathrm{v}_{2} \mathrm{O}_{3}$ & 0.50 & 0.85 & 0.40 & 0.65 \\
\hline $\mathrm{FeO}^{*}$ & 70.4 & 71.5 & 72.1 & 69.9 \\
\hline $\mathrm{MnO}$ & 0.51 & 0.45 & 0.52 & 0.45 \\
\hline $\mathrm{MgO}$ & 0.43 & 0.75 & 0.23 & 0.35 \\
\hline Total & 95.92 & 98.13 & 95.32 & 94.66 \\
\hline \multicolumn{5}{|l|}{ Recalculated } \\
\hline $\mathrm{FeO}$ & 49.8 & 49.8 & 48.2 & 48.6 \\
\hline $\mathrm{Fe}_{2} \mathrm{O}_{3}$ & 22.9 & 24.0 & 26.6 & 23.7 \\
\hline Total & 98.2 & 100.38 & 98.02 & 97.05 \\
\hline Usp & 65.3 & 63.8 & 59.8 & 63.6 \\
\hline
\end{tabular}

ing et al., 1976). According to the hypothesis of Schilling (1975), this archipelago probably represents material derived from a mantle plume rising beneath the islands. The effects of the mantle plume are observed as REE enrichment in rocks located up to $450 \mathrm{~km}$ from the center of the Galapagos archipelago; Site 424 is about $500 \mathrm{~km}$ away. 
TABLE 6

Representative Compositions ${ }^{\mathrm{a}}$ of Sulfide Grains in Basalt from Sites 424 and 425, Galapagos Spreading Center, East Pacific Ocean

\begin{tabular}{|c|c|c|c|c|c|c|c|c|c|}
\hline \multirow[b]{2}{*}{ u } & \multicolumn{4}{|c|}{ Section 424-4-6 } & \multicolumn{4}{|c|}{ Section 424-6-2 } & \multirow{2}{*}{$\begin{array}{r}\text { Section } \\
425-7-2\end{array}$} \\
\hline & - & 18.2 & 0.55 & 22.0 & 24.1 & 0.15 & 18.1 & - & \\
\hline & - & & & & 0.12 & 1.1 & 0.32 & 0 & 0.20 \\
\hline $\mathrm{Fe}$ & 59.2 & 43.2 & 58.2 & 42 & 38.8 & 59.0 & & 59.4 & 58.5 \\
\hline & 38.1 & 35.2 & 37.8 & 34.5 & 34.5 & 36.9 & 34.9 & 38.9 & 38.6 \\
\hline Total & 97.3 & 96.6 & 97.06 & 99.12 & 97.52 & 97.15 & 98.12 & 98.3 & 97.4 \\
\hline
\end{tabular}

aSome analyses total low, owing to small grain sizes and pitted surfaces.

FETI basalts relatively enriched in light REE are not unique to the Galapagos Islands. Similar REE patterns (Figure 8) and LIL element concentrations are displayed by ferrobasalts of the aseismic Ninetyeast Ridge (Thompson et al., 1978; Ludden et al., 1977) and the Mozambique Ridge (Berkley, 1977) of the Indian Ocean, indicating a possible mantle-plume source for these basalts as well.

Computer modeling (Clague and Bunch, 1976; Schilling et al., 1976) has shown that the origin of FETI basalts can be explained by shallow-level crystal fractionation. Given "normal"' mid-ocean ridge basalt as a parent, ferrobasalts can be produced by the fractionation of largely plagioclase (which accounts for the negative Eu anomaly) and smaller amounts of clinopyroxene and lesser olivine. Clague and Bunch (1976) compute respective proportions for these fractionating phases of 9.3:7.7:1. Our least-square calculations (Wright and Doherty, 1970) for generating the Site 424 FETI basalts from a Site 425 parent (Section 425-9-2) suggest that the weight proportions of the fractionating phases are 12.8:11.3:1 for clinopyroxene, plagioclase, and olivine, respectively (residuals for each oxide are less than 1 per cent of the amounts present when comparing the calculated parent rock with an actual parent rock). This fractionation scheme requires about 50 per cent crystallization. Since significant clinopyroxene fractionation can cause a light-REE enrichment in residual liquid, the light REE-depleted patterns displayed by Site 424 basalts (Figure 8) suggest derivation from a hypothetical parent which may have been even more depleted in light REE than the Site 424 basalt.

Assuming the parent basalt for Site 424 crystallized clinopyroxene, plagioclase, and olivine in the proportions 12.8:11.3:1 (50 per cent crystallization), we used appropriate partition (mineral/liquid) coefficient data and trace-element abundances in average Site 424 basalt to calculate expected trace-element concentrations in its parent. The calculated values (in ppm) are: $\mathrm{La} 1.84, \mathrm{Ce}$ 7.7, Nd 6.1, Sm 2.68, Eu 0.95, Tb 0.65, Dy 4.8, Yb 3.0, Lu 0.45 , Sc 78, Co 50, and Ni 108. The expected REE pattern (Figure 8) has no Eu-anomaly and is similar to the lowest REE-abundance patterns observed in the abundance range for "normal" ocean ridge basalts. The $\mathrm{Sc}$ value of $78 \mathrm{ppm}$ is high compared with Sc abundances commonly observed for ocean ridge basalts that have similar REE patterns (e.g., 42 to $51 \mathrm{ppm}$; Berkley, 1977). However, since the calculated Sc abundance is strongly dependent on the $\mathrm{D}(\mathrm{s} / \ell)$ value for clinopyroxene, lowering of the $D_{\mathrm{Sc}}$ (cpx/liq) from 3.3 to 2.0 produces agreement between expected and observed Sc abundances in ocean ridge basalts with low REE-abundances. Reductions in either the quantities of fractionally crystallized olivine and clinopyroxene, or in the values of the partition coefficients for $\mathrm{Ni}$ in these minerals, will lower the expected Ni content of $108 \mathrm{ppm}$ to values more in line with the observed $71 \mathrm{ppm}$ of $\mathrm{Ni}$ in Section 425-9-2 basalt (Table 1).

The contribution of clinopyroxene as a fractionating phase in the generation of FETI basalts is significant, because this phase is believed to have a relatively unimportant role in fractionation of "normal" oceanic tholeiite (e.g., Frey et al., 1974; Shibata, 1976). The relative effects of more or less clinopyroxene fractionation on bulk chemistry are shown in Figure 11. "Normal" ridgetype tholeiites generally lie along a plagioclase subtraction line, whereas FETI basalts lie along a vector more influenced by clinopyroxene subtraction (Figure 11). Assuming shallow-level fractionation for FETI basalts, significant clinopyroxene fractionation is expected. In the basalt system, Fo-An-Qz (e.g., Walker et al., 1972) cotectic crystallization of olivine and plagioclase is followed by clinopyroxene plus plagioclase crystallization at advanced stages of fractionation. Thus, the most highly fractionated oceanic basalts, such as the Site 424 basalts, are the most likely basalts to show evidence for significant clinopyroxene fractionation.

Based largely on $\mathrm{FeO}^{*} / \mathrm{MgO}$ and low LIL contents, Site 425 basalts are much closer to primitive basalt than the FETI basalts from Site 424 . Yet their moderate $\mathrm{MgO}$ and low Ni contents indicate that they have undergone at least some fractional crystallization. The most primitive basalts from mid-ocean ridge environments are considered to have $\mathrm{MgO}>8.0$ weight per cent (i.e., a slightly lower $\mathrm{FeO} * / \mathrm{MgO}$ ratio than that of 1.4 for the Site 425 basalts; Frey et al., 1974; Thompson et al., 1976). Our computer modeling suggests that Site 425 basalts may be the product of about 28 per cent fractional crystallization of plagioclase $\left(\mathrm{An}_{70}\right)$ and olivine $\left(\mathrm{Fo}_{90}\right)$ in the proportion $3: 1$, respectively, from a primitive tholeiite composition similar to that given by Frey et al. (1974; table 3 , analysis 7). No clinopyroxene was needed to produce the resultant least-squares fit. Thus, in terms of fractionation history, the Site 425 basalts represent moderately fractionated oceanic tholeiites derived from a more primitive tholeiite parent by mainly plagioclase plus olivine fractionation. On the other hand, the Ferich Site 424 basalts represent highly fractionated magmas derived from a light REE and LIL element-depleted parent, possibly similar in composition to the Site 425 basalts.

\section{ACKNOWLEDGMENTS}

This work was supported in parts by the National Aeronautics and Space Administration, Grants NGL 32-004-064 (K. Keil, principal investigator), Grant NGL 39-002-039 (R. A. Schmitt, principal investigator), and by the Engineering Foundation of North Carolina State University. 


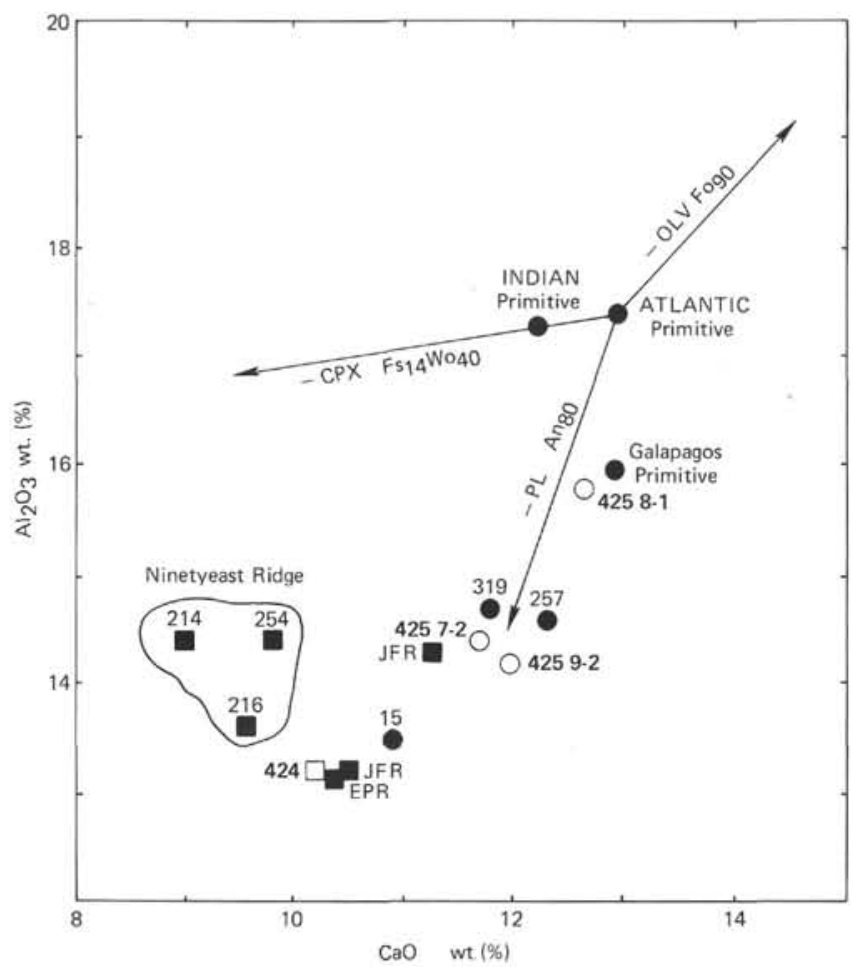

Figure 11. Plot of bulk $\mathrm{Al}_{2} \mathrm{O}_{3}$ versus $\mathrm{CaO}$ in weight per cent for Site 424 FETI basalts and Site 425 tholeiites, with comparative analyses and pertinent phenocryst subtraction lines. Circles are for "normal" oceanic tholeiites; squares are for ferrobasalts; open symbols represent analyses from this report. Comparative analyses: Atlantic primitive oceanic basalt and highly fractionated Site 15 glass from Frey et al. (1974); Indian Ocean primitive and other basalts from Ninetyeast Ridge (averages from Sites 214, 216, 254, 257) from Berkley (1977); Galapagos primitive basalt (Sample D-7) from Anderson et al. (1975); Site 319 represents the high $\mathrm{MgO} / \mathrm{FeO}$ * basalt from the $\mathrm{Naz}$ ca plate from Thompson et al. (1976); ferrobasalts from the East Pacific Rise (EPR), and Juan de Fuca Ridge (JFR) from Clague and Bunch (1976).

\section{REFERENCES}

Albee, A. L. and Ray, L., 1970. Correction factors for electron probe microanalysis of silicates, oxides, carbonates, phosphates, and sulfates, Anal. Chem., v. 42, p. 14081414.

Anderson, R. N., Clague, D. A., Klitgord, K. D., Marshall, M., and Nishimori, R. K., 1975. Magnetic and petrologic variations along the Galapagos spreading center and their relation to the Galapagos melting anomaly, Geol. Soc. Am. Bull., v. 86, p. 683-694.

Bence, A. E. and Albee, A. L., 1968. Empirical correction factors for the electron microanalysis of silicates and oxides, $J$. Geol., v. 76, p. 382-403.

Berkley, J. L., 1977. A petrochemical characterization of certain subaqueous DSDP basalts and andesites from the Indian Ocean, Unpublished Ph.D. dissertation, University of New Mexico.
Bonatti, E., Guerstein-Honnorez, B-M., and Hornorez, J., 1976. Copper-iron sulfide mineralizations from the equatorial mid-Atlantic ridge, Econ. Geol., v. 71, p. 1515-1525.

Clague, D. A. and Bunch, T. E., 1976. Formation of ferrobasalt at East Pacific midocean spreading centers, J. Geophys. Res., v. 81 , p. 4247-4256.

Corliss, T. B. and Ballard, R. D., 1977. Oasis of life in the cold abyss, National Geogr., v. 152, p. 441-453.

Czamanske, G. K and Moore, J. G., 1977. Composition and phase chemistry of sulfide globules in basalt from the MidAtlantic Ridge rift valley near $37^{\circ} \mathrm{N}$ lat, Geol. Soc. Am. Bull., v. 88 , p. 587-599.

Desborough, G. A., Anderson, A. T., and Wright, T. L., 1968. Mineralogy of sulfides from certain Hawaiian basalts, Econ. Geol., v. 63, p. 636-644.

Engel, A. E., Engel, C. G., and Havens, R. G., 1965. Chemical characteristics of oceanic basalts and the upper mantle, Geol. Soc. Am. Bull., v. 76, p. 719-734.

Fodor, R.V., Husler, J. W., and Keil, K., 1977. Petrology of basalt recovered during DSDP Leg 39B. In Supko, P. R., Perch-Nielsen, K., et al., Initial Reports of the Deep Sea Drilling Project, v. 39: Washington (U.S. Government Printing Office), p. 513-523.

Fodor, R. V., Keil, K., and Bunch, T. E., 1975. Contributions to the mineral chemistry of Hawaiian rocks IV. Pyroxenes in rocks from Haleakala and West Maui volcanoes, Maui, Hawaii, Contrib. Mineral. Petrol., v. 50, p. 173-195.

Frey, F. A., Bryan, W. B., and Thompson, G., 1974. Atlantic Ocean floor: geochemistry and petrology of basalts from Legs 2 and 3 of the Deep Sea Drilling Project, J. Geophys. Res., v. 79, p. 5507-5527.

Kay, R. W. and Hubbard, N. J., 1978. Trace elements in ocean ridge basalts, Earth. Planet. Sci. Lett., v. 38, p. 95-116.

Kay, R. W., Hubbard, N. J., and Gast, P. W., 1970. Chemical characteristics and origin of oceanic ridge volcanic rocks, $J$. Geophys. Res., v. 75, p. 1585-1613.

Keil, K., Fodor, R. V., and Bunch, T. E., 1972. Contributions to the mineral chemistry of Hawaiian rocks II. Feldspars in rocks from Haleakala and West Maui volcanoes, Maui, Hawaii, Contrib. Mineral. Petrol., v. 37, p. 253-276.

Kempe, D. R. C., 1976. Petrological studies on DSDP Leg 34 basalts: Nazca plate, eastern Pacific Ocean. In Yeats, R. S., Hart, S. R., et al., Initial Reports of the Deep Sea Drilling Project, v. 34: Washington (U.S. Government Printing Office), p. 189-213.

Lonsdale, P., 1977. Deep-tow observations at the mounds abyssal hydrothermal field, Galapagos rift, Earth Planet. Sci. Lett., v. 36, p. 92.

Ludden, J., Thompson, G., and Bryan, W. B., 1977. An evaluation of fractional crystallization and the origin of lavas from the $90^{\circ} \mathrm{E}$ ridge, eastern Indian Ocean, Geol. Soc. Am. Abstracts with Programs, v. 9, p. 1077-1078.

Mathez, E. A. and Yeats, R. S., 1976. Magnetic sulfides in basalt glass from DSDP Hole 319A and Site 320, Nazca plate. In Yeats, R. S., Hart, S. R., et al., Initial Reports of the Deep Sea Drilling Project, v. 34: Washington (U.S. Government Printing Office), p. 363-374.

Mazzullo, L. J., Bence, A. F., and Papike, J. J., 1976. Petrography and phase chemistry of basalts from DSDP Leg 34, Nazca plate. In Yeats, R. S., Hart. S. R., et al., Initial Reports of the Deep Sea Drilling Project, v. 34: Washington (U.S. Government Printing Office), p. 245-262.

Melson, W. G., Vallier, T. L., Wright, T. L., Byerly, G., and Nelen, J., 1976. Chemical diversity of abyssal volcanic glass 
erupted along Pacific, Atlantic, and Indian Ocean sea-floor spreading centers, Am. Geophys. Union Mono. 19, p. 351-367.

Rona, P. A., 1978. Criteria for recognition of hydrothermal mineral deposits in oceanic crust, Econ. Geol., v. 73, p. 135-160.

Schilling, J-G., 1975. Azores mantle blob: rare-earth evidence, Earth Planet. Sci. Lett., v. 25, p. 103-115.

Schilling, J-G., Anderson, R. N., and Vogt., P., 1976. Rare earth, $\mathrm{Fe}$ and $\mathrm{Ti}$ variations along the Galapagos spreading centre, and their relationship to the Galapagos mantle plume, Nature, v. 261, p. 108-113.

Schilling, J-G. and Bonatti, E., 1975 . East Pacific ridge $\left(2^{\circ} \mathrm{S}-\right.$ $\left.19^{\circ} \mathrm{S}\right)$ versus Nazca intraplate volcanism: rare-earth evidence, Earth Planet. Sci. Lett., v. 25, p. 93-102.

Sclater, J. G. and Klitgord, K. D., 1973. A detailed heat flow, topographic and magnetic survey across the Galapagos spreading centre at $86^{\circ} \mathrm{W}$, J. Geophys. Res., v. 78, p. 69516975.

Shibata, T., 1976. Phenocryst-bulk rock composition relations of abyssal tholeiites and their petrologic significance, Geochim. Cosmochim. Acta, v. 40, p. 1407-1417.
Thompson, F., Bryan, W. B., Frey, F. A., and Dickey, T. S., 1978. Basalts and related rocks from Deep Sea Drilling sites in the central and eastern Indian Ocean, Marine Geol., v. 26, p. 119-138.

Thompson, F., Bryan, W. B., Frey, F. A., Dickey, T. S., and Suen, C. J., 1976. Petrology and geochemistry of basalt from DSDP Leg 34, Nazca Plate. In Yeats, R. S., Hart, S. R., et al., Initial Reports of the Deep Sea Drilling Project, v. 34: Washington (U.S. Government Printing Office), p. 215-226.

Walker, D., Langhi, T., and Hays, T. F., 1972. Experimental petrology and origin of Fra Mau rocks and soil, Proc. Third Lunar Sci. Conf., v. 1, p. 797-817.

Williams, D. L., von Herzen, R., Sclater, R. P., and Anderson, R. N., 1974. The Galapagos spreading centre: lithospheric cooling and hydrothermal circulation, Geophys. J. Roy. Astron. Soc., v. 38, p. 587-608.

Wright, T. and Doherty, P., 1970. A linear programming and least squares computer method for solving petrologic mixing problems, Geol. Soc. Am. Bull., v. 81, p. 1995-2008. 